\title{
DE OPIUM-CONFERENTIE TE 'S-GRAVENHAGE EN DE DOOR HAAR GESLOTEN INTERNATIONALE
}

OVEREENKOMST.

Onder de internationale tractaten van den laatsten tijd mag de Opium-overeenkomst van 23 Januari 1912 een eenigszins bijzondere genoemd worden; niet alleen wat aangaat de materie, welke zij regelt, maar evenzeer wat aangaat het karakter, hetwelk daaraan verbonden is. Zeker doet deze overeenkomst meer dan eenige andere het zien en gevoelen hoe intens in de laatste tientallen van jaren de verhoudingen der verschillende Staten in internationaal opzicht zijn geworden; hoe de belangen van het eene land nauw grijpen in die van het andere en hoe de splitsing van deze belangen naar het territoir van ieder der Rijken in dezen tijd onmogelijk meer is door te voeren. Want wat is het doel en de strekking dezer Opium-conventie? In hoofdzaak bedoelt zij één Staat, het groote en uitgebreide Chineesche Rijk, te helpen in zijn strijd tegen de verderfelijke gevolgen van het opium, en zulks tegen de directe belangen der medewerkende partijen in, te meer misschien nog tegen deze belangen in, wanneer men bedenkt, dat juist het jonge China, hetwelk den innerlijken opium-oorlog heeft aangebonden, het ontwakende China is, dat menigeen met bezorgdheid doet denken aan het "gevaar van het Uiterste Oosten". Ongetwijfeld heeft de hulp, die aan China wordt verleend, ook een rechtstreekschen gunstigen invloed op de koloniën van de Mogendheden, welke deze hulp geven; ongetwijfeld is deze hulp ook niet zonder voordacht verleend in dit opzicht, dat men al dan niet zonder reden een overslaan van de opiumplaag van het Oosten naar het Westen vreest. Doch tegenover het groote belang, dat voor China bij het uitroeien van den opium-geesel voorop staat, mogen deze overwegingen van secundairen aard geheeten worden. En zeker van zoodanigen aard tegenover de directe nadeelen, die dadelijk voortvloeien uit het verminderde 
gebruik van opium in China, op welk gebruik althans in Britsch-Indië geheel eene industrie is gegrondvest.

Men kan zich voorstellen, dat zoodanig toegeven aan eischen die tegen 't eigen belang ingaan, geschiedt uit overwegingen van economischen en socialen aard en men kan dit prijzen even sterk als men het zou mogen afkeuren wanneer die overwegingen geen gewicht in den schaal legden; doch men mag het verklaarbaar achten, dat voor dit toegeven wordt gewenscht eenige zekerheid, dat het nadeel hetwelk wordt geleden, ook ten goede komt aan het afschaffen van het bestreden misbruik. Men mag het daarom billijk achten dat de Staten, die in dit opzicht met China contracteeren, eenigen waarborg verlangen, dat de verminderde invoer van opium werkelijk ook tot vermindering van het misbruik leidt; men mag het evenzeer billijk achten dat die Staten, welke voornamelijk bij den opiuminvoer zijn betrokken, zich op het standpunt stellen dat tegelijkertijd gewaakt moet worden tegen den invoer van soortgelijke schadelijke middelen als het opium, welke deze zouden kunnen vervangen en daardoor geheel het nuttig effect van den verminderden opiuminvoer zouden teniet doen. Men gevoelt uit deze overwegingen alleen reeds, hoe ingewikkeld dit vraagstuk door den omvang, welken het misbruik sedert jaren heeft genomen, geworden is; hoe het hier niet met een enkel woord gezegd kan worden dat men China moet bijstaan in zijn lofwaardige pogingen om het opiummisbruik te keeren, maar dat men alle gevolgen, welke uit eenigen maatregel dienaangaande kunnen voortspruiten, moet overwegen alvorens tot zulke maatregelen over te gaan.

Want het geldt hier niet een toestand die van den jongsten tijd dateert; het geldt hier een toestand niet van tientallen, maar van honderdtallen jaren her. In hoeverre de Chineezen, die er op wijzen, dat twaalf eeuwen achtereen de papaver bekend was en dat meer dan negen eeuwen het medicinaal gebruik van opium teruggaat alvorens het giftig misbruik, dat uit dezezelfde plant kan worden getrokken, werd ontdekt, gelijk hebben wanneer zij beweren dat het de vreemdelingen zijn geweest, die de ellende van het opiumschuiven in hun land hebben gebracht, is moeilijk met juistheid uit 
te maken. Maar zeker is het wel dat het de vreemdelingen en vooral de Portugeezen, die daarmede reeds in de zestiende eeuw aanvingen, zijn geweest, welke China voorzagen van dat vreeselijk voortbrengsel van diezelfde papaver, de opium. Tot ongeveer 1720 is de invoer van opium een monopolie van Indië gebleven; toen werden door keizer Jung Sjeng de strenge edicten tegen den opiumhandel uitgevaardigd, die echter dank zij den smokkelhandel slechts dit resultaat hadden, dat de invoer, welke in 1729 gerekend werd op 200 chests, in 1790 op 4000 chests moest worden geschat! Geen wonder, dat in de internationale handelsverdragen, welke China in het begin der negentiende eeuw meer en meer genoodzaakt werd met de Mogendheden van het Westen te sluiten, opium geen geringe plaats innam; geen wonder ook dat de zending van de keizerlijke commissarissen naar Kanton in 1839 , die de edicten van 1800 , welke in scherpen vorm tegen het opiumgebruik waren gericht, letterlijk wilden toepassen en daartoe geheel den opium-voorraad der vreemde importeurs deden vernietigen, den dusgenaamden Opium-oorlog veroorzaakte, welke een zwarte bladzijde vormt in de Engelsche diplomatieke geschiedenis, maar welke tenslotte zijn gezegende gevolgen heeft gevonden in de daardoor ontstane anti-opiumbeweging, die zich in Engeland en andere koloniale Rijken vanaf dien dag met groote kracht heeft doen gelden en op resultaten van beteekenis heeft kunnen wijzen. Niets is dan ook nagelaten om het tractaat van Nanking van 1844, dat China tegen zijn wil den opiuminvoer oplegde, te wijzigen, en stuksgewijze is dit verkregen. Doch alleen dan kon van een resultaat van beteekenis worden gesproken wanneer China zelf ernstig het gevaar van dien opiuminvoer begon te erkennen; wanneer China zelf zich met kracht daartegen verzette en den strijd aanbond tegen een invloed, welke voor het ontwakende China een invloed van vitaal belang moest heeten.

Dit te hebben gedaan, te hebben gedaan met een forsche hand, is zonder twijfel de beteekenis van het edict van 1906 . Het schiep de bekende draconische maatregelen tegen het opiumgebruik, en beval, dat al de plaatsen waar opium gemaakt en verkocht werd, binnen zes maanden moesten 
worden gesloten; dat alle Chineezen onder de zestig jaar hun gebruik van opium met $20 \mathrm{pCt}$. moesten verminderen en anders uit hunne betrekking ontzet en van hunne graden vervallen zouden worden verklaard; dat in tien jaren tijds alle opiumfabrieken en papaveraanplantingen anders dan tot eenig medicinaal doeleinde, moesten vervallen en dat daartoe telken jare $10 \mathrm{pCt}$. van de daarvoor bestemde gronden aan dit gebruik zou worden onttrokken. In den aanvang haalde men begrijpelijkerwijze de schouders op over deze strenge maatregelen; men kende China te goed om er groot gewicht aan te hechten; en des te strenger de maatregelen werden uitgevaardigd, des te minder geloofde men aan de verwezenlijking ervan. De uitkomsten leerden echter anders. De bepalingen werden met vaste hand doorgevoerd; keizerlijke commissarissen werden naar de verst afgelegen streken gezonden om aan den ernst der voorschriften kracht bij te zetten en al mag het twijfelachtig heeten of thans, nadat het edict ruim zes jaren in werking is geweest, ook inderdaad meer dan de helft van de papaveraanplantingen is verdwenen, aan de beteekenis der maatregelen mag niet meer worden getwijfeld. Had men tevoren wel, wanneer China zich verzette tegen den invoer van opium en wanneer van de zijde der anti-opiumbonders zulk een dwang een zedelooze dwang werd genoemd, de zaak nuchter bezien, misschien wat al te nuchter; had zelfs een man als Sir Robert Hart, overigens een goed vriend der Chineezen, zich min of meer sceptisch over geheel het vraagstuk uitgelaten; het edict van 1906, een der voornaamste uitingen van den jong-Chineeschen geest, heeft wel getoond dat het ontwakend China althans zijn eigen fouten kent en erkent; dat het gevoelt wat het innerlijk verslapt en verslapt heeft eeuwen achtereen. Zonder dienaangaande bepaalde bedoelingen te willen leggen in de houding der Mogendheden, mag toch zeker erkend worden dat het niet zonder opzet is geweest, dat aan het ethisch belang van het tegengaan van het opiumgebruik voor China, van dien kant weinig of geen waarde werd gehecht.

Men zou kunnen meenen dat tenslotte de vermindering van het opiumgebruik een interne zaak is, welke China 
alleen aangaat, en welke het naar eigen goedvinden kan regelen. En men zou juist meenen, indien China niet in de afgeloopen tientallen van jaren volkenrechterlijk eene bijzondere positie had ingenomen en geheel daarnaar is behandeld geworden. China kon het edict van 1906 uitvaardigen en de fabricatie van opium, den aanplant van de papaver in eigen land verbieden, maar het kon niet verhinderen zonder nadere medewerking van de Mogendheden, dat de invoer van buiten geschiedde en met te grooter kracht zou worden voortgezet naarmate China zelf aan de behoeften van het opiumgebruik niet meer zou kunnen voldoen. De handelstractaten, gegrondvest op het gebruik van vorige eeuwen, lagen daar als evenzoovele banden, welke de Chineesche regeering in hare handelingen bonden en dat deze banden niet zonder beteekenis waren, kan daaruit geleerd worden, dat de invoer van opium in het jaar 1907 in China bedroeg $3.299 .766 .55 \mathrm{Kg}$. waarvan niet minder dan 3.209.510.22 Kg. op Britsch-Indische papavervelden was gegroeid.

Hoe reusachtig groot dit cijfer is, zelfs voor een Rijk als China, mag wel daaruit worden afgeleid, dat in datzelfde jaar de invoer in Indo-China "slechts" bedroeg 37.929.84 Kg.; in Japan 74.377; op Formosa 145.773.07, in de Nederlandsche Kolonien 203.265,00, in Siam 83.727.41, terwijl bovendien in Honkong, in Kiatsjau en in Kwantung nog ingebracht werden hoeveelheden respectievelijk van $22.741 .105,00,8.697 .97$ en $445.36 \mathrm{Kg}$., welke alle natuurlijk ook haar weg in China zelf hebben gevonden. Het behoeft na deze cijfers geen betoog meer hoezeer het Engeland is, dat de voornaamste opiumbelangen tegenover China vertegenwoordigt, en hoezeer dus dit Rijk voor alles moest worden gekend in de veranderingen der internationale handelsbetrekkingen, door het edict van 1906 noodzakelijk gemaakt. Er zijn langdurige onderhandelingen te dien opzichte gevoerd en zij hebben, onder den invloed der liberale regeering, geleid tot het "Agreement" van 8 Mei 1911, hetwelk de bezegeling inhoudt van wat Engeland aan China heeft beloofd voor de naaste toekomst. Hierbij stemde Engeland erin toe in de eerstvolgende zeven jaren den opiuminvoer uit Britsch-Indie in zoodanige gelijke mate als 
het verbruik in China zelf afneemt, te verminderen, dat in 1917 deze invoer geheel zal hebben opgehouden. Het verkreeg daartoe bij dezelfde conventie uitgestrekte macht teneinde na te gaan in hoeverre China aan de gegeven beloften voldoet: waarborgen dus om zich met eigen oogen te overtuigen, dat niet de vermindering van den Indischen export slechts leidt tot bevoordeeling der Chineesche industrie zonder het opiummisbruik in eenig opzicht tegen te gaan. Het is dit Agreement, dat tot model heeft gediend voor de onderhandelingen, welke China vervolgens heeft aangeknoopt met de andere Staten, bij het opiumvraagstuk betrokken, en welke voor een groot deél reeds tot resultaten van beteekenis hebben geleid.

Tegelijk daarmede echter was erkend, dat het opiumvraagstuk moest worden genoemd een internationaal viaagstuk en niet tot China alleen beperkt kon worden geacht. Temeer gold ;it, omdat werkelijk het gevaar niet denkbeeldig mocht heeten dat het opiumgebruik en in nog sterker mate het misbruik, waarvan men China wilde bevrijden, van het Oosten zou overslaan naar het Westen en aldus zou teisteren die Staten, welke aan China de helpende hand wenschten te reiken. Amerika is het geweest, hetwelk op deze beteekenis van het vraagstuk de aandacht heeft gevestigd en hetwelk er op heeft aangedrongen om terwille van beschaving en ethiek China de hand te reiken, doch tegelijk onderling zoodanige waarborgen te stellen, dat van het overslaan van het gevaar geen sprake kon zijn. Daarvoor achtte Amerika, het jongste der koloniseerende Rijken van den Archipel, reeds voor het Agreement van 1911 eene internationale conferentie noodzakelijk en daartoe kwam in het begin van 1909 te Sjanghai de dusgenaamde Internationale Commissie bijeen. Zij had een gedeeltelijk diplomatiek, een gedeeltelijk ook wetenschappelijk karakter; haar was niet opgedragen om bindende besluiten te nemen, doch haar strekte slechts tot taak om haar gevoelen neer te leggen in resoluties, waarvan de beteekenis natuurlijk door niemand werd ontkend. De negen conclusies, waartoe zij gekomen is, geven dit gemengde karakter harer opdracht volkomen weer; in de eerste vier erkende zij den krachtigen wil van het Chineesche gouvernement om het opiummisbruik uit 
te roeien en beval den Mogendheden aan eensgezind daartoe mede te werken, en slechts het medicinaal gebruik der opium toe te staan, bovendien het groote gevaar van den smokkelhandel voor alles tegen te gaan. In de vijf overige conclusien bewoog zij zich meer op wetenschappelijk terrein, en kwam ook op de bestrijding van morphine, cocaïne en dergelijke bedwelmende middelen, welker verbod zij te noodzakelijker oordeelde naarmate het gemis aan opium de lieden daarnaar zou doen grijpen. Zij drong bij de Mogendheden die vestigingen in China hebben, op sluiting van alle opiumgelegenheden in dit gebied aan, wilde beperken of verbieden de fabricatie van de zoogenaamde geneesmiddelen tegen opium en wilde de pharmaceutische wetten van elk der landen van toepassing verklaren op hunne onderdanen in China.

Wat de Commissie van Sjanghai had gebracht, was niet anders dan een rapport, waardoor de regeeringen der Staten over het opiumvraagstuk konden oordeelen. Het werd daarna zaak om in den geest van het te Sjanghai geconstateerde, eene diplomatieke conventie af te sluiten, welke de noodige verbodsbepalingen in gemeenschappelijk overleg zou bevatten teneinde de resultaten te verkrijgen, die men te Sjanghai had mogelijk geoordeeld. Amerika, hetwelk het initiatief had genomen, ging voort op den ingeslagen weg en het was dank zij zijn krachtig aandringen en zijne bemiddeling, dat eindelijk in December 1911 de diplomatieke conferentie, welke op den grondslag der resoluties van Sjanghai haar werk had te verrichten, te 's-Gravenhage kon worden bijeengeroepen. De onderhandelingen, welke noodig bleken alvorens tot deze samenroeping |kon worden overgegaan, waren vooral te wijten aan de bezwaren van den sterk geïnteresseerden Engelschen Staat zonder welks medewerking aan het opiumvraagstuk inderdaad moeilijk eenige oplossing van beteekenis ware te geven geweest. En Engeland stelde zich op het geheel billijke standpunt, dat het bereid was tot de groote opofferingen, die de Britsch-Indische opiumindustrie zich zou moeten getroosten, tot de aderlating welke de Britsch-Indissche schatkist zou moeten ondergaan, indien slechts werd voldaan aan den eisch, dat niet het eenig resultaat van de beperking van 
den opiuminvoer daarin gelegen zou zijn dat andere schadelijke middelen de bedwelming in China brachten, welk een groot deel der bevolking er thans zoekt. Het wilde daarom de beperking van den opiuminvoer alleen dan bespreken wanneer daaraan werd verbonden de beperking van den invoer dier schadelijke middelen als morphine en cocaïne welker fabricatie voor Duitschland zoo groote beteekenis heeft. En Duitschland zijnerzijds aarzelde tegenover de belangen, die daarbij op het spel stonden; gevoelde tegelijk het bezwaar, dat het den invoer van zijne fabrieken kon stuiten zonder daarom den waarborg te hebben dat in een of ander land, hetwelk thans met de fabricatie der schadelijke middelen niets te maken heeft, fabrieken daartoe zouden verrijzen, en de voordeelen dier industrie Duitschland zouden ontnemen, zonder iets van het voordeel, hetwelk moreel voor het Chineesche volk beoogd werd, te hebben gebracht. Portugal, sterk belanghebbend door de onmiddellijke nabijheid van Macao; Perzie en Siam, evenmin onverschillig tegenover het opiumvraagstuk staande, gaven mede hunne bezwaren te kennen en leidden er toe, dat de sfeer, waarin zich de Haagsche conferentie moest bewegen, er eene was van groote omzichtigheid, van nimmer uitgesproken doch steeds economisch gevoeld en diplomatiek gevoed wantrouwen, van voortdurend opnieuw formuleeren en amendeeren van voorstellen. Dat op deze wijze de voortgang, die daar gewenscht werd, niet in een enkele week tijds kon worden verkregen, mag niet verwonderen; dat betrekkelijk zoo spoedig, in nog geen twee maanden tijds het resultaat bereikt werd als met de Opium-conventie bereikt is, mag verheugen. Wie zorgvuldig de protocollen dezer conferentie naleest, zal op elke bladzijde terugvinden de groote moeilijkheden, aan elke eerste regeling van een ingewikkeld vraagstuk als dit uit den aard der zaak verbonden en zal moeten erkennen dat dit verdrag, van zakelijk en nuchter standpunt beschouwd misschien van geringe waarde, zeer groote en inderdaad beteekenisvolle resultaten inhoudt, wanneer het wordt bezien uit het oogpunt der bezwaren, welke voor het sluiten van dit tractaat te overwinnen waren. 
De internationale overeenkomst, die in de diplomatieke stukken bekend zal staan als de Internationale Opium-Conventie van 's-Gravenhage van 23 Januari 1912, en die het resultaat werd van het bijna twee maanden achtereen arbeiden der daartoe bijeengeroepen conferentie, bestaat uit zes hoofdstukken, die elk voor zich een der belangrijke onderdeelen van dit verdrag regelen. Het eerste hoofdstuk behandelt het ruwe opium, het "opium brut"; het tweede hoofdstuk het voor gebruik bereide opium, het „opium préparé"; het derde hoofdstuk het medicinale opium en tegelijkertijd de morphine, de cocaïne en andere dergelijke schadelijke voortbrengselen; het vierde hoofdstuk enkele maatregelen, ten opzichte van China in het bijzonder aangegaan en toepasselijk verklaard ook voor deze conventie; het vijfde hoofdstuk enkele algemeene maatregelen ten opzichte van alle schadelijke middelen, in deze conventie behandeld; het zesde hoofdstuk de slotbepalingen betreffende de onderteekening, de bekrachtiging en de opzegging, bepalingen, welke in dit tractaat van meer dan gewoon belang zijn.

Als elke conventie vangt ook dit verdrag aan met eene korte inleiding, waarin hier de verdragsluitende Mogendheden verklaren een stap verder te willen zetten op den weg, betreden door de Internationale Commissie te Sjanghai, en waarin zij zich besloten verklaren om doeltreffende maatregelen te nemen tot het geleidelijk tegengaan van het misbruik van opium, morphine, cocaïne en dergelijke middelen of hunne bestanddeelen, die reeds tot misbruik hebben aanleiding gegeven of eenmaal kunnen geven. De verdragsluitende partijen erkennen voorts te dezen opzichte de noodzakelijdheid en het wederzijdsch voordeel van eene internationale samenwerking, en overtuigd als zij zijn, dat zij in deze menschlievende poging de eendrachtige medewerking van alle belanghebbende Staten zullen mogen ondervinden, geven zij aan haar voornemen uiting om in eene internationale conventie vast te leggen die maatregelen, welke door hunne gevolmachtigden, ter conferentie te 's-Gravenhage aanwezig, nuttig en noodig worden verklaard.

Het eerste hoofdstuk, het hoofdstuk dus van het ruwe opium, vangt evenals de hoofdstukken II en III met eene zeer nauwkeurige en vrij uitvoerige definitie van het be- 
standdeel, hetwelk het behandelt, aan; definities, die door het zoogenaamde Technisch Comité uit de gedelegeerden zijn opgemaakt en meermalen gedurende de beraadslagingen nog opnieuw aan een zorgvuldig onderzoek zijn onderworpen. Ten opzichte van het ruwe opium verklaren de verdragsluitende Staten, dat zij doeltreffende wetten of reglementen zullen uitvaardigen voor het toezicht op de voortbrenging en verspreiding van dit opium, tenzij bestaande wetten of reglementen dit onderwerp reeds hebben behandeld (Art. 1). Zij verklaren eveneens dat zij, daarbij rekening houdende met het verschil in wederzijdsche handelstoestanden, zullen beperken het aantal steden, havens of andere plaatsen, langs welke invoer of uitvoer van opium geoorloofd zal zijn (Art. 2). Zij zullen maatregelen nemen om den uitvoer van ruw opium te verhinderen naar landen, die den invoer daarvan hebben verboden, en om toezicht uit te oefenen op den uitvoer naar landen, die den invoer hebben beperkt; tenzij reeds bestaande maatregelen in dit onderwerp hebben voorzien (Art. 3). De verdragsluitende Mogendheden zullen voorts reglementen uitvaardigen, welke tengevolge moeten hebben, dat elk pakje, ruw opium inhoudende en bestemd voor den uitvoer, gewaarmerkt zal zijn op zoodanige wijze, dat zijn inhoud daardoor bekend wordt, mits dit pakje de 5 K.G. te boven gaat (Art. 4). De verdragsluitende Mogendheden zullen bovendien den invoer en den uitvoer van ruw opium slechts toelaten door personen, die daartoe volgens bepaalde voorschriften zijn gemachtigd (Art. 5).

Men kan aan dit eerste hoofdstuk, hetwelk deels aan Engelsche, deels aan Amerikaansche resoluties zijn ontstaan dankt, geen al te groote strengheid in de omschrijving der begrippen toekennen. Integendeel, wat het zegt, is eigenlijk niet meer den een algemeene beginselverklaring ten opzichte van de bestrijding van het opium-gevaar in internationalen zin, en deze beginselverklaring laat aan de Mogendheden, die verdragsluitende partijen zijn, vrijwel geheel en al de vrije keuze in de wijze om deze maatregelen uit te voeren. Het moet erkend worden, dat ten opzichte van dit uitvoeren der verplichtingen weinig of geen beperkende bepalingen in de conventie worden aangetroffen; de eenige uitdrukking, die in deze vijf artikelen eene beperking zou 
kunnen heeten is de uitdrukking: „tenzij bestaande maatregelen reeds in dit onderwerp hebben voorzien," en deze uitdrukking kan men toch moeilijk eene beperking noemen, daar zij alleen terugwijst op reeds vroeger genomen maatregelen van diezelfde Mogendheden, en dezen daarvan niet ontheft, maar hier uitsluitend machtigt om ook op deze maatregelen, welke aan het sluiten der Haagsche Conventie zijn voorafgegaan, een beroep te doen als op maatregelen, welke aan hare bepalingen beantwoorden. Aan den anderen kant scheen het op dit oogenblik meer dan ooit bezwaarlijk om meer in het bijzonder verplichtingen ten opzichte van de bestrijding van opium-misbruik in eene internationale acte vast te leggen; algemeen werd het standpunt ingenomen, dat tegenover de vrij groote onbekendheid der te behandelen stof, de Mogendheden zich niet konden binden aan voorschriften, welke op dit oogenblik niet in hare wetten zijn opgenomen, en welke haar dus zouden noodzaken om die wetten geheel te wijzigen en aan te vullen. Echter moet wel gezegd worden dat in de vijf artikelen, gewijd aan het ruwe opium, alle punten zijn geregeld, welke door de Internationale Commissie van Sjanghai als regeling behoevende waren voorgesteld en dat dus in dit opzicht vrijwel aan het programma der conferentie is voldaan; vrijwel en niet meer, en bovendien met uitzondering van een enkel punt, dat echter evenzeer voor hoofdstuk II als voor hoofdstuk I ter sprake kan komen.

De Mogendheden blijven thans in het eerste artikel geheel vrij aangaande de draagwijdte, welke zij aan de uit te vaardigen wetten en reglementen willen geven en moeten zelf beoordeelen of deze "doeltreffend', zijn; zij blijven eveneens vrij in het beperken van het aantal der havens; en de woorden, die in dit artikel in den oorspronkelijken tekst zijn ingelascht: „rekening houdende met de verschillen van hare handelstoestanden" zijn te dezen opzichte geen rechtstreeksche beperking, maar toch wel in zooverre, dat zij aan bijzondere uitlegging het nakomen der verplichting onderhevig maken. Eveneens blijven de Mogendheden vrij wat betreft de maatregelen zelven, welke zij moeten nemen om den uitvoer van alle opium te verhinderen naar die landen, welke den invoer geheel hebben verboden, en om 
toezicht te houden, dat de maat van den invoer niet overschreden wordt naar die landen, welke den invoer aan eenige beperking hebben onderworpen. Alleen bij zeer loyale uivoering van dit artikel en bij oprecht wederzijdsch vertrouwen, dat in dit opiumvraagstuk bij dit bijzondere punt met meer recht mag worden verondersteld dan in het algemeen bij tractaats-bepalingen, zullen hier conflicten kunnen worden voorkomen. Hoezeer echter ook omtrent dit punt tweeërlei uitlegging kan bestaan, bleek reeds bij een der lezingen van het ontwerp, toen van bepaalden kant ten aanzien van de verplichting van het geheel verbieden van den uitvoer van opium naar landen, die den invoer hebben verboden, de beperking werd voorgesteld, dat dit verbod zou ingaan binnen zoo kort mogelijken tijd, eene beperking die echter niet kon worden opgenomen. Oorspronkelijk was ten opzichte van dit artikel in den tekst neergeschreven, dat de bedoelde maatregelen genomen konden worden ook bij afzonderlijk verdrag of langs een anderen diplomatieken weg; deze woorden zijn geschrapt, omdat men er niet ten onrechte eene verzwakking van de tractaatrechtelijke verplichtingen in zag en tegelijk voor moeilijkheden in de uitlegging ging vreezen. In hoeverre de verplichting, in het vierde artikel der conventie genoemd, uitvoerbaar kan heeten, dient te worden afgewacht; dat echter het nut en de wenschelijkheid van een dergelijk waarmerken is erkend, is een stap van niet geringe beteekenis. En evenzoo mag het een onschatbaar voordeel worden genoemd, dat de Mogendheden er algemeen door de twee eenvoudige regeltjes, die het vijfde artikel samenstellen, in hebben toegestemd om de personen, die voortaan bij in- en uitvoer van opium zullen zijn betrokken, alleen dan toe te laten, indien zij door de regeering zelve zijn gemachtigd en dus aan bepaalde eischen van eerlijkheid en nauwgezetheid in hun handel voldoen. Het dient hier bij dit eerste hoofdstuk gezegd te worden, wat voor deze geheele conventie geldt, dat zij niet meer is dan een eerste stap op een moeilijken weg. Een weg, welke te moeilijker is, omdat een precedent van een zoodanig verdrag en met een zoo groot geldingsgebied, moeilijk te vinden zal zijn. Waarbij niet mag worden vergeten, dat uit een oogpunt van handel zoowel als naar 
financieelen maatstaf belangen van volstrekt tegenovergestelden aard in het spel waren; belangen, die het ieder voor zich wettigden, dat het betreffende land daarvoor strijd en moeite overhad.

Het tweede hoofdstuk handelt over het voor gebruik bereide opium, en bevat slechts drie artikelen, die deze stof in beginsel vrijwel op dezelfde wijze regelen als hoofdstuk 1 dit doet ten opzichte van het ruwe opium. De Mogendheden verplichten zich in 't algemeen maatregelen te nemen tot geleidelijke en doeltreffende afschaffing van de vervaardiging, den inlandschen handel en het gebruik van opium, een en ander binnen de grenzen, die de verschillende omstandigheden, waarin de verschillende landen verkeeren, vanzelf stellen, en ook hier weer in zooverre bestaande maatregelen niet reeds in het onderwerp hebben voorzien (Art. 6).

De Mogendheden verklaren verder den uitvoer van alle bereide opium te zullen verbieden; een uitzondering wordt hier slechts gemaakt voor die landen, waarvoor dit verbod een levensvraag van economischen of financieelen aard beteekent, en die dus, naar de woorden van de conventie geacht moeten worden: "nog niet gereed te zijn om den uitvoer van dit opium onmiddellijk te verhinderen"; zij verplichten zich door deze conventie om tot het verbod van dien uitvoer zoo spoedig mogelijk over te gaan, waarbij de belanger der overige in deze zaak betrokken Mogendheden voldoenden waarborg zijn, om aan te nemen, dat het niet aan elk toezicht voor het nakomen van deze verplichtingen zal ontbreken (Art. 7). Bovendien verplichten zich de Mogendheden, die nog niet gereed zijn om dadelijk allen uitvoer van bereide opium te verbieden, om: $1^{0}$ te beperken het aantal der steden, havens en andere plaatsen, van waar dit opium mag worden verscheept; $2 \circ$ den uitvoer van die opium te verbieden naar die landen, welke er thans den invoer van tegengaan, en evenzoo naar die landen, welke dit in de naaste toekomst zullen doen ; 30 te beletten, dat bereid opium gezonden wordt naar een land; dat den uitdrukkelijken wensch te kennen heeft gegeven, den invoer van dit opium te beperken, tenzij de uitvoerder zich geheel en al gedraagt naar de desbetreffende reglementen van het betrokken 
land; 4o, zorg te dragen dat elk uitgevoerd pakje bereid opium een bijzonder merk draagt, hetwelk zijn inhoud aanwijst: $5^{\circ}$ den uitvoer van bereid opium slechts toe te staan aan de personen, die daarvoor eene bijzondere vergunning hebben (Art. 8).

Men zal moeten erkennen, dat, zijn deze bepalingen algemeen, - en wat wenscht men anders van eene algemeene conventie, die toch waarlijk geen voorschriften met bijzonderheden kan bevatten, welke naar den aard, de omstandigheden en de belangen voor elk land anders zullen moeten luiden, misschien ook niet voor elk deel van een land gelijk zullen zijn - zij moeilijk een strenger en beslissender toon konden aanslaan. De vervaardiging van opium wordt op deze wijze wel zeer streng in den weg getreden, want al wordt tegen de eigenlijke vervaardiging geen enkele bepaling gemaakt, en al worden de verdragsluitende Mogendheden slechts door art. 6 verplicht om mede te werken deze vervaardiging „zoo spoedig mogelijk langs geleidelijken weg te doen ophouden; toch moet men erkennen, dat waar de uitvoer getroffen wordt, de vervaardiging zelve in nog veel sterker mate getroffen wordt. Immers, in het eigen land zal men voor dit bereide opium geen afzetgebied kunnen vinden; uit eigenbelang zal de betrokken regeering daar wel voor zorgen; en de uitvoer wordt aan zeer scherpe bepalingen onderworpen, welke, zijn zij misschien ook ondanks het best denkbare toezicht te overtreden, toch in elk geval dit niet geringe voordeel hebben, dat zij den uitvoer in hooge mate bemoeilijken, voor een deel zelfs beletten en den uitvoer onttrekken aan de handen dergenen, die op een eerlijken en onbevlekten handelsnaam prijs stellen. Evenzeer geldt dit indirect van het beperken van den aanplant van papaver; ook het tegengaan hiervan, allhans het tegengaan van de uitbreiding, was een punt op het voorloopig Amerikaansch programma, doch men gevoelt hoe zeer het onnoodig wordt om uitdrukkelijk van den papaveraanplant te spreken, wanneer men langs den omweg van belemmering van den uitvoer, de opium-vervaardiging zelve gaat treffen. Men zou zelfs kunnen zeggen, dat dit thans nog beter geregeld is dan wanneer de papaveraanplant zonder meer was beperkt of 
verboden geworden. Wie weet, welke heilzame middelen deze wonderschoone bloem nog in zich bergt, en welk bezwaar bestaat er tegen haar aanplant, wanneer zij niet meer is de bittere kelk, die de opium-ellende aan een groot deel der menschheid te drinken geeft?

De beperkingen, welke de Mogendneden ten opzichte van het bereide opium op zich hebben genomen, zijn welbezien van grooter beteekenis dan die aangaande het ruwe opium, en temeer mag het ons daarom verheugen, dat deze maatregelen zoo scherp zijn omschreven. Ook hier geldt het weer, dat in de artikelen niet meer dan algemeene begrippen zijn neergeschreven, en dat het vrijwel aan elk der verdragsluitende partijen vrij staat om deze begrippen telkens uit te leggen en uit te voeren naar eigen inzicht; maar men moet daarbij niet vergeten, dat behalve wederzijdsche gevoelens ook wederzijdsche belangen van niet onbelangrijken aard in het spel zijn. Deze wederzijdsche belangen zullen er zeker toe bijdragen, dat elk der partijen zich onder anderer toezicht en aandacht weet, en ook in haar eigen belang - want de eene afwijking zou zoo licht de andere medebrengen - het inachtnemen der bepalingen niet zal verzuimen. Men moet evenmin ten opzichte van dit hoofdstuk uit het oog verliezen, dat deze Opium-conventie niet is een gewoon verdrag, maar tevens in zekeren zin een handelstractaat tusschen een groot aantal partijen en over een bepaalde stof, waarin de handel voor een volk in economisch opzicht van zeer nadeelige gevolgen is. $\mathrm{Er}$ is zeker geen land, dat voor zijn eigen grondgebied of voor zijne koloniën het opiumgebruik zal wenschen; evenmin een land, dat bij voorkeur zijn handel zal zien bloeien door het brengen van opium-vergif onder andere volkeren; onze bedoelingen mogen niet altijd de edelste zijn, zoover zijn de volkeren gelukkig nog niet gezonken. Maar er zijn in dit onderwerp, en vooral op het gebied der vervaardiging, wederzijdsche belangen in het spel, welke van dien aard zijn, dat heel moeilijk geëischt of ook maar verwacht kan worden, dat eenig land zich zonder meer aan verbodsbepalingen zou binden, die geen humanitair voordeel zullen geven, maar slechts kunnen strekken tot voordeel van een mededinger. Zoodoende kan men bij dit tractaat ook spreken 
van cen proef op groote schaal; een proef, waarvan wij alleen kunnen hopen, dat zij slaagt, maar een proef, waarvan het tegelijkertijd een geluk is, dat zij niet voor den eersten keer in een al te eng kleed is gestoken.

Met eenige bevreemding zal men misschien zoowel in het hoofdstuk van ruw opium als in dat van bereid opium eenige bepaling missen omtrent den smokkelhandel, die vooral in het opiumvraagstuk een zoo gewichtige plaats inneemt. Het punt kwam voor op het Amerikaansche programma en werd daarin zelfs vrij sterk uitgedrukt door aan te dringen op het wederzijdsche recht van onderzoek van schepen, die van opium-smokkelen worden verdacht. Reeds het feit alleen, dat het noodzakelijk scheen om dit aan een tegengaan van den smokkelhandel min of meer rechtstreeks te verbinden, wees in hooge mate op de moeilijkheden, die een tractaatsbepaling voor het tegengaan van dien smokkelhandel in zich bergt. Men denke echter niet, dat de Haagsche conferentie het punt geheel onopgemerkt heeft laten voorbijgaan, en het is ook hier evenals drie jaren daarvoor in Shanghai de Nederlandsche delegatie geweest, die op de belangrijkheid van dit punt den nadruk heeft gelegd, en maatregelen in dien zin zoo uitgebreid mogelijk heeft voorgesteld. Van Nederlandsche zijde was zelfs een ontwerp van een aantal artikelen ingediend, dat tegelijkertijd bedoelde den alleenhandel in opium van regeeringswege voor alle belanghebbende landen vast te stellen en afdoende den smokkelhandel te weren. Het ontwerp verwees daarbij naar de verklaringen, die dienaangaande in de zittingen der Commissie van Shanghai door den bekwamen Nederlandschen gedelegeerde, den heer A. A. de Jongh, destijds Inspecteur-Generaal der Opium-Regie in de Nederlandsch-Indische Koloniën waren afgelegd. Deze had er op gewezen, dat alleen dan, wanneer de regeeringen geheel den opiumhandel in handen zullen hebben, het mogelijk zal zijn met onverstoorbare kracht tegen te gaan de pogingen van hen, die dit ellendig middel willen brengen tot verderf van de menschen; van hen, die het dezen willen brengen tot eigen voordeel en er dus op uit zijn, dat men meer en meer van dit middel gebruiken zal. Uit den aard der zaak zou het instellen van een 
opiumregie, die zoowel de vervaardiging als den handel beheerscht, voor elk land een geheelen ommekeer teweegbrengen in de tot dusver gevolgde opium-politiek, en daartegenover stond dan als soort van contra-prestatie de verbintenis der Mogendheden, dat zij geen ander opium op hun gebied zouden toelaten. Dan ware het niet noodig, gelijk te Shanghai wel geschiedde, te spreken over den smokkelhandel in het bijzonder, want men gevoelt, dat wanneer alle landen de opium-regie ter hand gaan nemen, wanneer dus in alle landen en koloniën slechts het eigen product van het gouvernement zal worden toegelaten en herkenbaar gemaakt, het smokkelen met zoodanige moeilijkheden zal gepaard gaan, dat er geen sprake van kan zijn er voordeel mede te behalen. Men verlieze hierbij echter niet uit het oog, dat rechtstreeksche maatregelen tegen den smokkelhandel in den Oost-Indischen Archipel en langs de grenzen van het Chineesche Rijk in afdoenden zin feitelijk onmogelijk zijn; de smokkelaars zelven beschikken over zooveel middelen, die niet dan met uiterste krachtsinspanning te keeren zullen zijn; zij staan in zoovele opzichten in het voordeel tegenover de regeeringen, dat een doelmatige bestrijding vrijwel uitgesloten is. Het kan niet ontkend worden, dat ook de thans genomen maatregelen'dien smokkelhandel zeer bemoeilijken - gelukkig - , dat naarmate de geest van deze maatregelen meer en meer zal doordringen in het optreden van 'de regeeringen en hare ambtenaren, de smokkelhandel zich nieuwe banen zal moeten openen. Men moet eveneens niet vergeten te verwijzen naar het hoofdstuk van deze conventie, hetwelk in de artikelen 15 tot en met 19 maatregelen bevat, die vooral voor China en de met dit land door afzonderlijke tractaten verbonden Staten van beteekenis zijn.

In zooverre was het Nederlandsche ontwerp nog een gelukkige vernieuwing!

Het derde hoofdstuk van de conventie brengt ons tot het medicinale opium, de cocaïne, de heroïne en al dergelijke middelen, in de toekomst tenminste even schadelijk als thans het opium is, wanneer zij niet dadelijk worden bestreden. Het behoeft wel niet gezegd, naar aanleiding van de diplomatieke gedachtenwisseling, die voor den aanvang der conferentie reeds 
plaats had, dat de resoluties, welke voor de artikelen van dit hoofdstuk de bouwstoffen hebben geleverd, bijna uitsluitend van Engelschen kant afkomstig zijn. En ze zouden waarschijnlijk in hunne bewoordingen scherper zijn geweest, categorischer het morphine-gevaar en het bijkomende gevaar van andere dergelijke middelen hebben bestreden, ware niet van Duitschen kant op eenige verzachting der redactie aangedrongen terwille van de belangen, die vooral de Duitsche handel in deze materie kan aantoonen. Het hoofdstuk zou eveneens de codeïne reeds nu onder de schadelijke middelen, die rechtstreeks te bestrijden vallen, hebben opgenoemd, had niet ook de Duitsche delegatie hiertegen verzet doen gelden; verzet dat op den wetenschappelijken grond, waarop het door Duitschland was gebaseerd, werd aangevallen, maar waarbij men zich tenslotte neerlegde, voor een deel terwille van de noodzakelijke eenstemmigheid.

Thans zijn de Mogendheden overeengekomen om pharmaceutische wetten en reglementen uit te vaardigen teneinde de vervaardiging, den verkoop en het aanwenden van morphine, cocaine en al hare bestanddeelen te beperken tot medisch en ander uitsluitend wettelijk gebruik; ze zullen bovendien samenwerken, teneinde te verhinderen, dat deze middelen voor eenig ander doel worden aangewend. (Art. 9.) Daarnevens zijn de verdragsluitende partijen overeengekomen dat zij pogingen in het werk zullen stellen om toezicht uit te oefenen of te doen uitoefenen op allen, die morphine, cocaïne of andere daarmede gelijkstaande middelen vervaardigen, invoeren, verkoopen, verspreiden of uitvoeren, en evenzoo op de gebouwen, waarin deze personen dit bedrijf of dezen handel uitoefenen; daartoe zullen zij pogingen in het werk stellen - ook hier weer die dubbelzinnige en in de overeenkomst zoo zwakke uitdrukking - om: $1^{\circ}$. tot de inrichtingen en lokalen, waarvoor machtiging verleend is, de vervaardiging van morphine, cocaïne e. a. te beperken of zich op de hoogte te stellen van alle inrichtingen en lokalen, waarin deze middelen worden vervaardigd, en daarvan een register op te maken; $2^{\circ}$ van allen, die morphine, cocaïne e. a. vervaardigen, invoeren, verkoopen, verspreiden en uitvoeren, te eischen, dat zij van de vergunning tot dit doel voorzien zijn of zich met een officieele 
verklaring dienaangaande hebben gewend tot de bevoegde autoriteiten; $3^{\circ}$. van deze personen te verlangen, dat zij in hunne boeken vermelden de vervaardigde hoeveelheden, de bedragen van invoer en verkoop, elke andere overdracht en de grootte van den uitvoer met betrekking tot morphine, cocaïne e.s., welke regel echter niet noodzakelijkerwijs van toepassing zal behoeven te worden verklaard op medische voorschriften en op verkoop, uitgeoefend door gevestigde apothekers (Art. 10). Vervolgens zullen de Mogendheden maatregelen nemen, om in haren binnenlandschen handel elke overdracht van morphine, cocaïne e. a. te beletten aan personen, die niet gemachtigd zijn deze in ontvangst te nemen (Art. 12), en evenzoo zullen zij, daarbij echter rekening houdend met het verschil van omstandigheden, waarin zij verkeeren, pogingen aanwenden om tot de daartoe gemachtigde personen den invoer van morphine, cocaïne e. a. te beperken. (Art. 12).

De Mogendheden hebben zich voorts verbonden om te trachten maatregelen te nemen of te doen nemen teneinde den uitvoer van morphine, cocaïne, e.a. vanuit hare landen, bezittingen, koloniën en pachtstaten naar die van andere verdragsluitende partijen te beperken tot personen, die volgens de wetten en reglementen van het ontvangende land daartoe gemachtigd zijn; te dien einde kan elke regeering van tijd tot tijd aan de regeeringen der landen, die uitvoeren, lijsten doen toekomen van de personen, aan wie de in artikel 12 bedoelde machtiging is gegeven. (Art. 13). En ten slotte zullen de verdragsluitende partijen de wetten en reglementen op vervaardiging, invoer, verkoop en uitvoer van morphine, cocaïne e. a. toepassen op medicinaal opium, op alle bereidingen, die meer dan $0,2 \mathrm{pCt}$. morphine of meer dan $0.1 \mathrm{pCt}$. cocaïne bevatten, op heroïne en op zijne bestanddeelen en bereidingen, die meer dan $0.1 \mathrm{pCt}$. heroïne bevatten; en in het algemeen op elk nieuw derivaat van morphine en cocaïne e. a. en op alle onderdeelen van het opium, welke tengevolge van wetenschappelijke onderzoekingen in het algemeen erkend worden tot gelijke misbruiken aanleiding te geven en tot dezelfde nadeelige gevolgen.

Wat ten opzichte van het eerste hoofdstuk der conventie 
gezegd is, kan ten opzichte van dit hoofdstuk niet worden herhaald. De woorden, waarin de tractaatrechterlijke verbintenis ligt opgesloten, de werkwoorden van deze artikelen zijn in tegenstelling met de twee voorgaande hoofdstukken veel minder krachtig en laten ruimte tot zeer bijzondere uitlegging van de algemeene verplichtingen te over. Niet zonder leedwezen dan ook en zonder tegenstand evenmin heeft, naar men zegt, Engeland in verzwakking van dit hoofdstuk toegestemd, maar de bezwaren van Duitschland waren zoo groot en zoo begrijpelijk, wanneer men de groote uitvoercijfers van Duitschland op dit gebied voor zich ziet, dat zonder toegeven zeer zeker de eenstemmigheid ernstig in gevaar zou zijn gebracht. Duitschland schijnt zich bovendien op het standpunt gesteld te hebben - in het algemeen een zeer juist beginsel, al mag men dit niet te breed uitmeten - dat het niet meer verplichtingen op zich wil nemen dan het zeker is te kunnen volbrengen. En ten opzichte van een zoo sterk toezicht op morphine, cocaïne e.a. als oorspronkeliik verlangd werd, gold voor zijne regeering dit bezwaar. Duitschland wil daarenboven slechts langs geleidelijken weg medewerken tot de bestrijding van het morphinegevaar en daaraan nauw verbonden gevaren van gelijken aard; Duitschland moet al weer hier met zijn handel en de mogelijkheid rekening houden, en heeft dientengevolge in het twaalfde artikel, dat den invoer beperkt, diezelfde woorden, die verschil erkennen in de handelstoestanden der verdragsluitende partijen - een voorbehoud, ten opzichte van het opium binnengehaald door een Fransch voorstel - ook op dezen invoer van toepassing weten te verkrijgen. Door de verzwakking, die in den loop der beraadslagingen is aangebracht, bemerkt men een zekere tweeslachtigheid in den tekst van dit hoofdstuk; het eerste artikel, dat als het ware als een beginselartikel zou mogen worden beschouwd, is veel forscher dan de andere artikelen en wekt eigenlijk de veronderstelling, dat het in de bedoeling ligt om geheel het bedrijf van morphine, cocainne e. a. tot het pharmaceutisch bedrijf te beperken.

Het vierde hoofdstuk behandelt verplichtingen, die speciaal China en de Staten, die door tractaten met dit land verbonden zijn, de zoogenaamde „Verdragstaten" wederzijds 
tegenover elkander aangaan. De Verdragstaten zullen in overeenstemming met de Chineesche regeering alle noodige maatregelen nemen om zoowel op Chineesch grondgebied als in hunne koloniën in het uiterste Oosten en in de pachtlanden, die zij in China bezitten, te beletten den smokkelhandel in ruw en bereid opium, in morphine, cocaïne, e.a.; en eveneens het binnensmokkelen van alle middelen, die door artikel 14 der conventie voor heden of voor de toekomst daarmede gelijkgesteld worden; China zal insgelijks doen ten opzichte van den smokkelhandel naar deze koloniën en deze pachtlanden (Art. 15). China zal bovendien pharmaceutische wetten uitvaardigen, die verkoop en verspreiding van morphine, cocaïne e.a. zullen regelen, welke wetten de Chineesche regeering langs diplomatieken weg aan de Verdragstaten zal mededeelen en welke deze, achten zij hare bepalingen aannemelijk, zullen doen toepassen op hunne onderdanen, die in China verblijf houden (Art. 16). De Verdragstaten zullen trachten te verkriigen, dat de noodige maatregelen leiden tot beperking van en toezicht op het opiumschuiven in de pachtlanden, nederzettingen en concessies, weike zij in China hebben; tot opheffing "pari passu" met de Chineesche regeling van de inrichtingen voor opiumschuiven, die daar nog zouden bestaan; en tot verbod van het gebruik van opium bij vermakelijkheden en in publieke huizen (Art. 17). De Verdragstaten zullen, ook hier op denzelfden voet als de Chineesche regeering, maatregelen nemen tot gelijdelijke vermindering van het aantal winkels voor den verkoop van ruw en bereid opium, welke nog bestaan in hunne pachtlanden, nederzettingen en concessies in China; zij zullen in elk geval overgaan tot doeltreffende maatregelen ter beperking van en toezicht op den detailhandel in opium in diezelfde streken (Art. 18). En bovendien zullen de Verdragstaten, die evenals zulks in Turkije het geval is, ook in China hunne eigen postkantoren hebben, afdoende maatregelen nemen om den invoer te verhinderen in den vorm van postpakketten en zoowel van ruw en van bereid opium, als van morphine, cocaïne e.a.; en evenzoo zullen zij zorgen, dat geen onwettige overbrenging per post plaats heeft van de eene plaats in China naar de andere door 
middel van deze kantoren (Art. 19). Bij de bepalingen van dit hoofdstuk waren slechts 10 van de 12 ter conferentie vertegenwoordigde Mogendheden betrokken; Perzië en Siam, die wel tractaten met China hebben, maar daarom niet tot de Verdragstaten behooren, hebben bij dit hoofdstuk geen belang en hebben deze opmerking aan hunne orderteekening toegevoegd.

Van hunne zijde werd zelfs gewenscht, dat deze bepalingen niet in de algemeene conventie zouden worden opgenomen doch zouden worden ondergebracht in een afzonderlijk verdrag, door China en de overige negen Mogendheden te onderteekenen; China van zijn kant daarentegen wees op de veel grootere beteekenis, die de daarin vastgelegde maatregelen verkrijgen, nu zij in het algemeen verdrag van 's-Gravenhage zijn neergeschreven en niet in een afzonderlijk verdrag, hetwelk geen tractaat van algemeen internationale beteekenis meer zou kunnen heeten. Perzië heeft hierbij zelfs gesproken van een technisch-volkenrechterlijke fout, die echter als zoodanig door den technisch zeer hoogstaanden adviseur van deze conferentie, wijlen Staatsraad Mr. T. M. C. Asser, niet is erkend geworden; in verband met de bijzondere materie, welke dit verdrag te regelen had, lijkt dit ook alleszins gewettigd en verklaarbaar. De OpiumConventie van 's Gravenhage van Januari 1912 toch is eene conventie, die dient ter bestrijding van het opiumgevaar en andere nauw daarmede verbonden gevaren; doordat de verplichtingen van China en de Verdragstaten in het algemeene verdrag zijn opgenomen, treden ook deze naar buiten te voorschijn als maatregelen, ondernomen op dit gebied; waren die bepalingen in een afzonderlijk verdrag ondergebracht, dan zouden zij slechts het effect van eene regeling op uitgebreider basis dan gewoonlijk hebben gehad, en het veel grooter effect van thans zou ook tegenover de later toegetreden Staten verloren zijn gegaan. De bepalingen zelven van het vierde hoofdstuk leggen niets in den weg tot inwilliging van China's wensch; integendeel, deze artikelen sluiten zich logisch bij de voorgaande artikelen aan, al mag het opmerking verdienen, dat de daarin uitgesproken gevoelens, welke door Chineesche resolutes in het debat zijn gebracht, nog in 1909 te Sjanghai minder instemming 
en minder tegemoetkoming ondervonden. De groote invloed, dien het Britsch-Chineesche „Opium-agreement" van Mei 1911 op geheel het opiumvraagstuk heeft uitgeoefend, valt ook hier niet te ontkennen; in de artikelen 17 en 18 vooral vindt men denzelfden gedachtengang terug, dien men ook in dat tractaat aantreft. De Mogendheden willen China te hulp komen in zijne bestrijding van het opium-misbruik, maar zij eischen, evenals Engeland dit in zijne particuliere onderhandelingen tevoren deed, de noodige waarborgen, dat vermindering van invoer en gebruik komen ten bate van de zaak der menschheid, waarvoor zij zijn aangegaan en niet ten bate van den Chineeschen opium-handel. Vandaar in die beide artikelen de beperking van het "pari passu" met de maatregelen der Chineesche regeering zonder dat men in deze artikelen tegelijkertijd de nauwer omschreven waarborgen van China verlangt, welke het Britsch-Chineesche Agreement wel vraagt. Voor een deel zeer zeker zijn zoodanige in bijzonderheden omschreven waarborgen hier moeilijker te vergen dan in een afzonderlijk tractaat van twee Mogendheden; voor een deel misschien heeft men ook thans meer vertrouwen in den Chineeschen ernst tot waarachtige doorvoering van het draconisch edict van 1906, dan te Sjanghai in 1909 op den grondslag der toen zeer gebrekkige Chineesche statistieken het geval kon zijn. China heeft sedert veel verbeterde en aangevulde statistieken overgelegd en bovendien is in dien tusschentijd gekomen het belangwekkende en nauwkeurige rapport van Sir Alexander Hosie, den Engelschen Regeerings-commissaris in China, hetwelk allen twijfel aan den ernst der Chineesche bedoelingen heeft kunnen opheffen. ${ }^{1}$ )

Het vijfde en eigenlijk het laatste hoofdstuk der werkelijke conventioneele bepalingen bevat twee artikelen van meer algemeene strekking, van toepassing op de eerste drie hoofdstukken. De verdragsluitende partijen zullen de mogelijkheid onderzoeken, om wetten en reglementen uit te vaardigen, die het onwettige bezit van opium, morphine, cocaïne e.a. strafbaar stellen (Art. 20). De Mogendheden

1) Ter tweede Opium-conferentie in Juli 1913 is nog eens opnieuw door de Chineesche gedelegeerclen de ernst dezer bedoelingen bevestigd; na het procesverbaal der tweede zitting. 
żullen bovendien door bemiddeling van het Nederlandsche Ministerie van Buitenlandsche Zaken wederkeerig uitwisselen de wetten en administratieve reglementen, die betrekking hebben op de onderwerpen dezer conventie, of naar aanleiding van hare bepalingen zijn uitgevaardigd geworden; en evenzoo statistische inlichtingen ten opzichte van den handel in opium, morphine, cocaïne e.a., zoo uitgebreid en zoo spoedig als dit slechts mogelijk is (Art. 21).

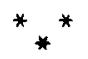

Het zesde en slothoofdstuk der conventie regelt de gewone beschikkingen van tractaatrechterlijken aard, de beschikkingen ten opzichte van onderteekening, toetreding, bekrachtiging en opzegging. Het hoofdstuk is bij deze conventie van grooter beteekenis dan bij eenig ander tractaat en geeft dan ook eene regeling te zien, die van de gewone geheel afwijkt. Regel van diplomatie is toch, dat de Mogendheden, die deelnemers zijn geweest aan de Conferentie, welke het verdrag heeft ontworpen, dit verdrag teekenen en bekrachtigen, en dat eerst daarna de Mogendheden, die niet ter conferentie hebben willen komen of om bijzondere redenen daartoe niet uitgenoodigd zijn geworden, in de gelegenheid worden gesteld eveneens tot het nieuwe internationale verband toe te treden; in meer dan een geval is het zelfs voorgekomen - men denke slechts aan den oorspronkelijken tekst van het Haagsche verdrag voor de beslechting van internationale geschillen van 1899 - dat men buiten de ter conferentie aanwezige Mogendheden geen andere wenschte toe te laten. In het Opiumverdrag is de regel omgekeerd, en is niet de toetreding van andere Mogendheden gesteld na de bekrachtiging, maar de bekrachtiging door de 12 te 's-Gravenhage vertegenwoordigde Mogendheden, en dus tegelijkertijd de rechtsgeldige inwerkingtreding van het tractaat, af hankelijk gesteld van de toetreding van de Mogendheden, die niet te 's-Gravenhage vertegenwoordigd waren. Artikel 22 der conventie regelde het aldus, dat de Nederlandsche regeering zoo spoedig mogelijk zich zou wenden tot alle Mogendheden van Europa en van Amerika, die niet ter conferentie aanwezig waren - een lijst van 34 namen werd aan het artikel toegevoegd waarbij de lijst der tweede Vredesconferentie is gebruikt, 
en dus nevens alle groote en kleine Mogendheden van Europa, ook Mexico en de Republieken van Zuid- en Midden-Amerika zijn opgenoemd geworden - teneinde deze uit te noodigen door een gedelegeerde, van volmachten voorzien, de conventie te doen teekenen, voor welke onderteekening een afzonderlijk protocol van aanvullende onderteekening zou worden aangelegd, hetwelk den datum van elke onderteekening zou bevatten. Zouden eenmaal alle aangeduide Mogendheden zoowel voor zichzelve als voor hare koloniën de conventie van hare handteekening voorzien hebben, dan kon de Nederlandsche regeering overgaan tot het uitnoodigen van alle Mogendheden, dus tot die, welke wel en welke niet te 's Gravenhage vertegenwoordigd waren, om het verdrag te bekrachtigen; zouden alle aanvullende onderteekeningen, die ingevolge art. 22 gewenscht werden, intusschen niet uiterlijk 31 December 1912 verkregen zijn, dan zou de Nederlandsche regeering al die Mogendheden, die dan het verdrag onderteekend hadden, uitnoodigen tot eene nadere conferente te 's-Gravenhage, om te overwegen in hoeverre toch reeds tot bekrachtiging kon worden overgegaan. Zoowel van de aanvullende onderteekeningen als van de bekrachtigingen zou de Nederlandsche regeering maandelijks kennis geven aan alle Mogendheden, die dan partij zijn, zoodra de laatste bekrachtiging was verkregen, werd dit bovendien afzonderlijk aan alle Mogendheden medegedeeld (Art. 23.).

$\mathrm{Na}$ de eventueele bekrachtiging de inwerkingtreding. Drie maanden na den datum van de laatste bekrachtiging treedt de conventie in werking. Ten opzichte van wetten en reglementen en andere maatregelen die door dit verdrag worden geeischt, is overeengekomen, dat de daartoe benoodigde ontwerpen uiterlijk zes maanden na de inwerkingtreding moeten zijn opgemaakt; wat bijzonderlijk de wetten aangaat, welke de goedkeuring der wetgevende lichamen behoeven, geldt, dat zij uiterlijk in die zes maanden moeten ingediend zijn, of kan zulks tijdens een recès niet geschieden, aan het begin der eerstvolgende parlementaire zitting. De datum, waarop deze reglementen en maatregelen in werking treden, zal het onderwerp uitmaken van een nieuw overleg tusschen de verdragsluitende partijen, waartoe de Nederland- 
sche regeering het initiatief op zich neemt. Evenzoo zal de Nederlandsche regeering het initiatief nemen om alle verdragsluitende partijen uit te noodigen tot het aanwijzen van gedelegeerden, die zich te 's Gravenhage voor het verkrijgen van eene onmiddellijke oplossing zullen vereenigen, in het geval moeilijkheden zouden ontstaan bij de bekrachtiging of inwerkingstelling van deze conventie, hetzij van de conventie zelve, hetzij van de maatregelen, reglementen en wetten, welke zij voorschrijft. Het schijnt ons toe, dat eene dergelijke conferentie niet het juist aangewezen middel mag worden geacht om een zoodanig technisch en diplomatiek, gedeeltelijk misschien ook juridisch en economisch conflict tot zoo spoedig mogelijke oplossing te brengen; het komt ons raadselachtig voor, dat bij deze bepaling vergeten is, dat slechts een zeer geringe afstand de aloude Ridderzaal waar. men vergaderde, scheidde van het Permanente Hof van Arbitrage, dat over eenigen tijd in het Vredespaleis gevestigd zou zijn. Wanneer er één soort van geschillen is, dat aan het Permanente Hof kan worden toevertrouwd, dan zijn het zeker wel die geschillen, die betrekking hebben op uitlegging en toepassing van een bestaand verdrag. Een dergelijk geschil is van zuiver juridischen aard, en heeft de meeste zekerheid naar recht en billijkheid, ook naar de beteekenis der conventie zelve, te worden opgelost, indien het voor het Permanente Hof komt. Dat aan deze oplossing niet gedacht is lijkt ons zeer te betreuren.

Regelt artikel 24 de inwerkingtreding der conventie, het laatste artikel (25) spreekt van de opzegging, die in den gewonen tekst van dergelijke bepalingen is vervat. Wil eenige Mogendheid tot deze opzegging overgaan, dan heeft zij dit schriftelijk aan de Nederlandsche regeering te melden, die daarvan mededeeling heeft te doen aan de andere verdragsluitende partijen; de opzegging heeft bovendien slechts kracht ten opzichte van de betreffende Mogendheid, en eerst een jaar na de mededeeling daarvan. Frankrijk en Engeland hebben ten opzichte van deze opzegging het gewone, tractaatrechterlijk verklaarbare voorbehoud gemaakt van afzonderlijke opzegging voor de koloniale Staten, die onder bepaalde vormen tot hun koloniaal bezit behooren.

Het vermoeden is zeker niet ongewettigd, dat de slot- 
bepalingen van deze conventie wel meer dan eens ter sprake zullen komen zoowel in dit geval zelf als daarbuiten. In zooverre is de afwijking van den gewonen regel hier te verklaren en te billijken, omdat het hier een bijzonder geval geldt. Immers, weliswaar zijn zeer terecht tot deze conferentie alleen uitgenoodigd die Staten, welke rechtstreeks bij het opium- en het morphinevraagstuk betrokken zijn; weliswaar hebben slechts deze Staten direct belang bij maatregelen ter beperking van dit misbruik, maar wanneer zij overgaan tot maatregelen, die hunne wederzijdsche nijverheid, welke zich met al deze verderfelijke middelen bezighoudt, aan banden legt met het doel deze eenmaal terug te geven aan uitsluitend medicinaal gebruik, dan kan het voor hen niet onbeteekenend zijn de zekerheid te hebben, dat niet een ander land, hetwelk thans tegenover opium en morphine zoo onverschillig mogelijk staat, gelegenheid tot gastvrijheid aanbiedt aan een nijverheid van gelijken aard, welke daar op de meest ongebreidelde wijze het bedrijf zou kunnen uitoefenen en bevoordeeld zou zijn boven de nijverheid van een der verdragsluitende Staten. In het Amerikaansche programma kwam deze vraag reeds om het hoekje kijken door den papaveraanplant in landen, die dezen thans niet hebben, voor altijd te willen verbieden; een verbod, dat ook dan slechts kracht zou kunnen hebben gehad, indien het zich tot geheel de wereld had uitgestrekt. En nog afgescheiden van het denkbeeldige gevaar - overigens niet zoo heel denkbeeldig - dat een of ander klein land daartoe zijn grondgebied beschikbaar zal stellen, werd met name gedacht aan Turkije, dat opium vervaardigt van zeer verdachte kwaliteit; aan Bolivia en Peru, die tegenover de morphine en cocaïne niet onschuldig staan. Het is gebleken uit wat van de gedachtewisseling ter conferentie reeds dadelijk openbaar is geworden, dat Engeland ten opzichte van het opium-bedrijf een dergelijke mededinging niet ducht; inderdaad is de handel in Engeland en in Britsch-Indië door het bijzonder tractaat met China zoo voldoende gedekt, dat deze vrees niet ter sprake behoefde te komen, terwijl de andere landen ten opzichte van hun opium in zoodanige omstandigheden verkeeren, dat de gebeurlijkheden in dit opzicht evenmin behoefden te worden gevreesd. 
Anders staat het echter voor Duitschland ten opzichte van morphine, cocaïne e.a.; Duitschland heeft hier zijn zeer uitgebreiden ook $\mathrm{chemischen} \mathrm{handel} \mathrm{te} \mathrm{waarborgen}$ en zich te verweren tegen het van uit het binnenland terecht te verwachten verwijt, dat deze conventie verplichtingen oplegt, die het terrein der menschlievendheid zouden overschrijden en aan den Duitschen handel nadeel zouden toebrengen. Van Duitschen kant is dan ook, hoewel betrekkelijk onverwachts, het verzet gekomen om in dit geval den gewonen gang van zaken bij de bekrachtiging niet te volgen; zoo onverwachts, dat men zich wel af te vragen had, of Duitschland niet beter gedaan had door op den voorgrond te stellen, dat het de tegenwoordigheid van alle Staten op deze conferentie wenschte, een aanwezigheid, waarover reeds in den aanvang der beraadslagingen door Perzië de strijd was aangebonden in eene resolutie, die de conferentie toen logisch moest voeren tot het uitnoodigen van alle Staten ter wereld om toe te treden.

$\mathrm{De}$ in beginsel tegenover elkander staande meeningen, die ten opzichte van de slotbepalingen werden gehuldigd, hebben het totstandkomen van overeenstemming niet gemakkelijk gemaakt en indien het Comité van Redactie, waarvan de Fransche gedelegeerde Brenier bij afwezigheid van den heer Guesde in die moeilijke periode het voorzitterschap voerde; waarvan leden waren de heeren Van Deventer, Sir William Collins, Savinsky en Delbrück, onderscheidenlijk gedelegeerden voor Nederland, Engeland, Rusland en Duitschland, niet den uitstekenden steun had gehad van technische en onpartijdige raadslieden als Staatsraad Asser en Nederland's Minister van Buitenlandsche Zaken, dan ware het wel te betwijfelen geweest of uit de moeilijkheden een uitweg zou zijn gevonden.

Een merkwaardig voorstel was het, dat in de laatste dagen van Amerikaansche zijde nog werd ingediend ten opzichte van de slotbepalingen; hel voorstel om de conventie in tweeën te scheiden en ervan te maken: een opiumconventie met de geworle slotbepalingen, dus bekrachtiging vóór de toetreding van andere Staten; en een conventie voor morphine, cocaïne e.a. met bijzondere slotbepalingen, dus bekrachtiging na toetreding van andere Staten. Duitsch- 
land, dat morphine en cocaïne niet onafscheidelijk aan opium verbonden had, maakte tegen eene dergelijke oplossing natuurlijk geen bezwaar, maar Engeland verzette zich er heftig tegen, omdat die splitsing zou brengen wat het had willen voorkomen; nl. dat de opiumbestrijding zou aanvangen op internationalen grondslag en met internationale middelen op een moment, dat eenzelfde bestrijding van morphine, cocaïne e.a. nog niet zoover was voorbereid, dat men verhinderen kon, dat het eene gevaar vervangen zou worden door het andere; dat dus ook de voordeelen, die Britsch-Indië nu geniet van een misbruik, waaraan China zedelijk te gronde gaat, zouden komen aan Duitschland. Zoo sterke tegenstand werd in de conferentie tegen dit Amerikaansche voorstel getoond, dat een motie van Russischen kant, welke het voorstel buiten de orde van het programma der conferentie noemde, met groote meerderheid werd aangenomen, om anders zeker te verwachten onaangename incidenten, te vermijden.

Ingevolge de bepalingen van het tractaat van 23 Januari 1912 bleef tot het einde van dat jaar de conventie ter teekening in additioneel protocol open voor de overige beschaafde landen der wereld. De twaalf ter conferentie vertegenwoordigde Staten teekenden alle het tractaat op den dag der sluiting, en Engeland voegde op 17 December 1912 zijn onderteekening daaraan toe voor geheel het uitgebreid koloniaal bezit van zijn Rijk. Costarica, Mexico, Guatemala, Luxemburg, Panama, Ecuador, Honduras, San Salvador, Haïti, Venezuela, Brazilië, Argentinië, Spanje, de Dominicaansche Republiek, Paraguay, Denemarken (mede voor IJsland) en België, dit laatste onder reserve van opzegging voor zooverre betreft den Congo teekenden alle in den loop van het jaar het protocol en traden dus tot het verdrag toe.

Aan het einde van 1912 was zoodoende het protocol voor de onderteekening van niet ter conferentie vertegenwoordigde Staten voorzien van de handteekeningen van de gedelegeerden van 17 zoodanige Staten, hetgeen met de ter conferentie toegetredenen een totaal aantal onderteekenaars van 29 maakte, waarbij zich na 1 Januari 1913 nog 
voegden Chili, Cuba, Bolivia, Columbia en Nicaragua. Degenen, die niet onderteekend hadden, waren in drie categorien in te deelen. De eerste bestond uit OostenrijkHongarije, uit Noorwegen en uit Zweden, die ter kennis van de Nederlandsche regeering brachten dat, aangezien vóór het in werking treden der conventie hun wetgeving noodig had eenige verandering te ondergaan, zij hunne onderteekening nog niet konden geven, terwijl zij in zachte termen twijfelden of nu juist voor het welslagen van den tegen het opiumgebruik gerichten arbeid hunne medewerking zoo groote noodzakelijkheid bood. De tweede categorie bestond eenerzijds uit Bulgarije en Uruguay, die een bevestigend antwoord op de vraag of zij mede wenschten te onderteekenen, hadden gegeven, doch zoodanige onderteekening nog niet hadden doen verrichten; en uit Roemenie, die het belang der aangelegenheid erkend had, doch welks Ministerie de stukken niet voldoende had onderzocht om reeds vóór het einde van het oude jaar een beslissing te kunnen geven; anderzijds uit Montenegro, Peru en Servie, die om voor een deel niet onbegrijpelijke redenen geen antwoord op de door Nederland tot hen gerichte uitnoodiging hadden gezonden. De derde categorie ten slotte bestond uit Griekenland, Zwitserland en Turkije, welke Staten allen hadden geantwoord $\mathrm{niet}$ te zullen onderteekenen en van welke Turkije uit economische overwegingen zulks weigerde, Griekenland geen redenen opgaf en Zwitserland betoogde dat het met opiumverbruik en opiumfabricatie zoo weinig in aanraking kwam, dat zijne al dan niet medewerking op de totstandkoming der conventie geen invloed kon oefenen.

Alzoo bleek het resultaat te zijn, dat vaststond de weigering van drie Staten om aan den arbeid der conventie deel te nemen en onder deze drie Staten was Turkije, van welks toetreding door Engeland en ook door Perzië niet onduidelijk een besliste voorwaarde was gemaakt; dat van een drietal andere Staten het antwoord nog twijfelachtig was en dat onder deze twijfelachtige antwoorden waren die van Servie en Peru, van welker voornemens ten opzichte van de fabricatie van met het opium gelijk te stellen verdoovingsmiddelen men nu juist geen te groote verwachtingen had. 
De onderteekening van alle uitgenoodigde Mogendheden was niet verkregen; aan de voorwaarde van artikel 23 der conventie van 1912 niet voldaan; tot ratificatie kon niet worden overgegaan. De Nederlandsche regeering riep dus de tweede opium-conferentie bijeen die in Juli 1913 zich verzamelde. Haar taak was volgens de duidelijke bepalingen van artikel 23 geen andere dan te constateeren de strekking van de ingekomen antwoorden en daarna te beslissen over de vraag of in verband met hetgeen ter eerste opiumconferentie was gezegd, thans aan het ratificeeren en het in werking treden der overeenkomst kon worden gedacht. Zij heeft deze taak niet volbracht; zij heeft haar zelfs niet aangevat en zij meende van den aanvang af wijs te doen deze houding aan te nemen, aangezien reeds onmiddellijk toen de vraag aan de vertegenwoordigde Staten werd voorgelegd of zij in deze omstandigheden zouden ratificeeren, de vraag der eenstemmigheid van overwegende beteekenis bleek.

Duitschland verklaarde, zich baseerende op de uiteenzetting ter eerste conferentie, dat het thans aan ratificatie niet kon denken, men behoefde zich maar te herinneren hoezeer Engeland zijne medewerking tot bestrijding van het opium afhankelijk heeft gesteld van de daarmede gepaard gaande bestrijding van morphine en cocaine, om te beseffen dat deze weigering op Engeland's voornemens tot ratificatie van overwegenden invloed zou zijn. Weliswaar bleek de groote meerderheid der vertegenwoordigde Staten bereid na goedkeuring van het Parlement tot ratificatie over te gaan, maar wat baatte deze ratificatie aan de zaak der opiumbestrijding zoolang Frankrijk haar slechts uitstrekte tot Europa en haar reserveerde voor de koloniën; zoolang de houding van Engeland niet vaststond en die van Duitschland weigerachtig bleef. Men gevoelde het op deze conferentie, dat het antwoord op de vraag, wat te doen zou zijn na ontvangst van de antwoorden der Staten, die niet op de eerste conferentie vertegenwoordigd waren, nog niet rijp was voor een beslissing; dat deze conferentie een middenweg diende te vinden om langer beraad mogelijk te maken.

De samenwerking van een zestal van de voornaamste ter conferentie vertegenwoordigde Staten, van Duitschland, 
Engeland, Frankrijk, Rusland, Amerika en Nederland heeft dezen middenweg gegeven. Een wensch werd door de vertegenwoordigers van deze zes Staten voorgesteld, welke het drieledig doel had: 1e. het Nederlandsche Gouvernement te verzoeken aan Oostenrijk-Hongarije, Noorwegen en Zweden te doen opmerken dat het nog niet in overeenstemming zijn hunner wetgeving met de bepalingen der conventie geen enkel bezwaar bood tegen de onderteekening van het aanvullend protocol, aangezien de conventie zelve een duidelijk verschil maakt tusschen de onderteekening, de inwerkingtreding en de wijzigingen der nationale wetten; $2 \mathrm{e}$. aan hetzelfde gouvernement te verzoeken onder de aandacht van Buigarije, Griekenland, Montenegro, Peru, Roemenië, Servië, Turkije en Uruguay te brengen de noodzakelijkheid van onderteekening door alle beschaafde Staten van deze overeenkomst, opdat haar doel zal kunnen worden bereikt; $3 \mathrm{e}$. aan hetzelfde gouvernement te vragen om den Zwitserschen Bondsraad te overtuigen hoezeer ook zijn onderteckening noodig is voor de gewenschte eenstemmigheid en hoezeer het bezwaar dat de cantonnale wetgeving niet gedwongen kan worden, in de conventie zelve is ondervangen. Deze wensch, aangevuld door de verplichting voor alle vertegenwoordigde Staten om hunne gezanten bij de betrokken regeeringen de stappen der Nederlandsche regeering te doen steunen, werd eenstemmig aanvaard; doch niet ten onrechte merkt de president der conferentie, de heer Cremer op, dat thans wel nieuwe stappen in het belang der algemeene zaak waren aangeduid, doch dat daaruit niet bleek wat te doen zou zijn teneinde tot de ratificatie te komen, ook in het geval, dat als mogelijk te veronderstellen bleef, dat de bij de weigerachtige Staten uitgeoefende pogingen geen slagen opleverden. De conferentie heeft door eene toevoeging aan den aangenomen wensch in deze leemte voorzien en bepaald dat, indien de onderteekening van de nog ontbrekende Staten uiterlijk 31 December 1913 niet is verkregen, een derde conferentie door de Nederlandsche regeering zoo spoedig mogelijk zal worden bijeengeroepen, met het dan niet meer te ontwijken doel om te onderzoeken de mogelijkheid van het in werking treden der conventie van 1912, niettegenstaande 
de afwezigheid van enkele der gewenschte handteekeningen. ')

Zoo heeft de tweede internationale opiumconferentie het beslissend oordeel dat van haar werd gevraagd overgedragen aan hare opvolgster, en men mag aannemen dat zij daarmede een verstandig besluit heeft genomen, dat zij door niet overhaast en niet overijld teveel te willen, voorkomen heeft wat anders vrij zeker dreigde; dit, dat geheel de arbeid van December 1911 en Januari 1912 zou zijn teniet gegaan, zou zijn gebleven papier zonder meer. Weliswaar is van een enkelen kant verzet gekomen tegen het uitstel dat zoodoende noodig is; weliswaar bleek er een zwakke strooming in deze conferentie te bestaan, die reeds thans wilde uitgemaakt zien of de conventie geratificeerd zou kunnen worden of zij in werking zou kunnen treden. In dit opzicht heeft deze conferentie echter goeden diplomatieken stijl getoond, heeft zij begrepen dat er in het internationale leven telkenmale oogenblikken zijn dat men den gang van zaken niet mag forceeren.

En dat zij zulks ten slotte eenstemmig heeft ingezien, heeft aan hare besluiten zeker moreel groote kracht verleend, doch is even ongetwijfeld voor een niet gering gedeelte te danken aan den tact en het inzicht waarmede de niet gemakkelijke arbeid dezer conferentie door den Nederlandschen eerste gedelegeerde den heer J. T. Cremer is geleid geworden.$$
\text { ** }
$$

In het slotprotokol, dat tegelijkertijd met de conventie op 23 Januari 1912 is geteekend, worden nevens de overeenkomst nog enkele wenschen vermeld, welke de conferentie in resoluties heeft aanvaard. Allereerst wordt de wenschelijkheid uitgesproken om de aandacht van de Wereld-PostVereeniging te vestigen op de noodzakelijkheid om de overbrenging van ruw opium per post tegen te gaan, eveneens, voor zooverre dit mogelijk is, van morphine, cocaïne e.a.; en dit te verbieden van bereid opium. Dit was een vraagstuk dat in de conferentie een punt van gewichtige bespreking

1) Sedert teekenden Peru en Uruguay reeds; Zweden en Noorwegen verklaarden zich bereid. Met Oostenrijk, Zwitserland en de Balkanstaten worden de onderhandelingen voortgezet. 
heeft uitgemaakt, gelijk zulks te Sjanghai reeds het geval was, omdat met maatregelen dienaangaande het briefgeheim verband houdt, en omdat daartegenover staat, dat voor het tegengaan van persoonlijk misbruik zoodanige maatregelen onmisbaar zijn, wijl door de practijk bewezen is, dat per post hoeveelheden kunnen worden toegezonden, die voor persoonlijk misbruik voldoende zijn en die zelfs misbruik in de naaste omgeving mede tengevolge kunnen hebben. Een tweede wensch geldt den Indischen hennep, waarvan de gevaarlijke hoedanigheden door de Italiaansche regeering reeds waren aangewezen bij haar antwoord op de Amerikaansche circulaire; haar voorstel om ook bestrijding van dit middel bij deze conferentie te bespreken was door alle deelhebbende Staten aanvaard geworden, doch daar de Italiaansche gedelegeerde, prof. Santoliquido door de Sanitaire Conferentie te Parijs werd verhinderd te 's-Gravenhage tegenwoordig te zijn, kwamen geen voorstellen van Italië dienaangaande in, en bepaalde men er zich toe, naar aanleiding van een voorstel van Nederlandsche zijde, om aan de gedachte uiting te geven, dat het goed zou zijn om dit vraagstuk uit statistisch en wetenschappelijk oogpunt te onderzoeken teneinde, indien eenmaal de noodzakelijkheid zich daartoe deed gevoelen, door internationale wetgeving of door internationaal overleg, misbruik van dezen aard te keeren. Een derde wensch, die in het bijzonder betrekking had op den invoer van Turksch en Perzisch opium, welke met ingang van 1 Januari 1812 in China is verboden geworden, is ten slotte, na aangenomen te zijn, uit het slot-protokol verwijderd, op voorstel van China zelf, dat door deze tegemoetkoming aan Perzië de gelegenheid gaf zijn voorbehoud in te trekken en de toetreding van Turkije minder bezwaarlijk te maken. Wat dit laatste betreft, intusschen voorloopig te vergeefs!

In hoeverre de afgesloten overeenkomst, overeenkomst trouwens nog altijd in ontwerp, kan voldoen aan de eischen van de kenners van koloniale toestanden der verschillende Rijken gelijk zij in het Internationaal Koloniaal Instituut vereenigd mogen worden geacht, valt op dit 
oogenblik moeilijk uit te maken. Weliswaar heeft het opiumvraagstuk, gelijk trouwens begrijpelijk is, meermalen de aandacht van het Koloniaal Instituut getrokken; in het bijzonder in de zitting, welke het Instituut in 1909 te 's Gravenhage hield, is over het opiummisbruik gesproken aan de hand van de inleiding, door den heer Mr. C. Th. van Deventer aan dit belangwekkende onderwerp op even belangwekkende wijze gewijd, doch de vraag in hoeverre maatregelen daartegen te beramen zouden zijn, werd er meer gesteld vanaf het standpunt van elk land en elke kolonie voor zichzelve dan wel vanaf het standpunt eener internationale samenwerking, die zich toen ook nog in slechts zeer vage omtrekken deed vermoeden. In de zitting, te Brunswijk in 1911 gehouden, kwam het vraagstuk opnieuw op het tapijt, thans onder een vorm, die veel meer in staat was om het sociaal belang in het algemeen te doen gevoelen, thans in verband met het niet minder ernstige probleem van het drankmisbruik. Reeds meermalen toch - het laatst in berichten uit China, die van het einde van 1910 dateeren - was aan de vrees uiting gegeven, dat het opiummisbruik slechts zou plaats maken voor het drankmisbruik, een vrees, welke door anderen geloochend werd op grond van de uitspraak, dat die deelen der bevolking, welke thans voor het opiummisbruik zoozeer vatbaar zijn, in niets de mogelijkheid rechtvaardigen, dat zij ook voor het drankmisbruik aanleg zouden toonen. Ter internationale Opiumconferentie is deze vraag niet onbesproken gelaten; de eerste Fransche gedelegeerde, de heer Guesde bracht haar in een der laatste zittingen naar voren, doch kon bijna onmiddellijk met eene verwijzing naar de betrekkelijk beperkte bevoegdheden dezer conferentie tot zwijgen worden gebracht. Inderdaad, op deze conferentie behoorde zij niet thuis; de Opium-conferentie had daartoe een samenkomst van wijder diplomatieke strekking moeten zijn en had zich dan zeker niet mogen beperken tot het gering aantal Staten, waartoe zij nu beperkt was. In de zitting van het Koloniaal Instituut te Brunswijk daarentegen werd het verband tusschen beide vraagstukken terdege besproken, allereerst door den rapporteur over de vraag van het drankmisbruik in de verschillende kolonien, ook ditmaal de heer Van Deventer; vervolgens door meerdere 
dergenen, die zich in het debat over deze aangelegenheid mengden; tenslotte door de niet geheel toevallige omstandigheid, dat nevens het rapport van den heer Van Deventer over maatregelen tegen drankmisbruik in de koloniën in het algemeen, afgedrukt was een rapport van den Franschen kolonialen deskundige, den graaf de Pouvourville over de maatregelen tegen het opiummisbruik in Indo-China. Het was echter toen tevens, dat er tegen gewaarschuwd werd om den wenk te volgen, dien den heer Chailly in de zitting van 's-Gravenhage van 1909 had gegeven en af te wijken van de statuten van het Instituut in dien geest, dat aan de regeeringen eenigermate een raad zou worden gegeven in welken geest het Instituut handelen noodig achtte. Men wenschte ook nu ten opzichte van deze toch voor de koloniën zoo levensgewichtige problemen het wetenschappelijk standpunt van het Instituut te handhaven; zich te bepalen tot een strikt wetenschappelijk en technisch onderzoek, en de resultaten van dezen arbeid ter beschikking te stellen van elke poging hetzij afzonderlijk hetzij in internationale samenwerking om te beteugelen de vreeselijkste kwaden, die over de koloniën zijn gebracht. Wat het Koloniaal Instituut wenscht en noodig acht in den strijd tegen het opiummisbruik, in eenige conclusie heeft het dit nimmer neergelegd; doch voor zooveel zijne beraadslagingen zijn te verstaan in den geest als het dit gewenscht heeft, mag toch wel worden geconstateerd, dat in elk geval het Haagsche verdrag ook voor haar eene eerste zij het ook zwakke poging is om door internationale samenwerking de resultaten te verkrijgen, die in dit opzicht voor elke kolonie noodzakelijk zijn.

Wat dan ook in 't algemeen te zeggen van wat met deze conventie is bereikt of binnenkort bereikt zal worden? Het spreekt vanzelf: een misbruik, dat zoo diep geworteld is als het misbruik van opium of van andere schadelijke middelen, roeit men niet uit met een enkel internatonaal tractraat, zelfs al zou men dit in den meest liberalen geest hebben opgesteld en op de meest loyale wijze kunnen en willen uitvoeren. Een vraagstuk, zoo ingewikkeld als het opiumvraagstuk met zijn financieele, economische, politieke vertakkingen, ruimt men niet door een enkele internationale conferentie uit den weg, en niemand zeker, die dit zal 
hebben verwacht. Met een overeenkomst als deze geeft men slechts het bewijs, dat men internationale samenwerking nuttig acht en onontbeerlijk tevens; en men stelt in zulk eene overeenkomst de algemeene beginselen vast, waarnaar men in samenwerking de bestrijding van het kwaad zal voeren. Dat in de Opiumconferentie veel, misschien te veel met wederzijdsche belangen moest worden rekening gehouden; dat omstandigheden van geografischen zoowel als van staatkundigen aard het noodzakelijk maakten te strenge omschrijvingen te vermijden, het is te betreuren en heeft zeker het verdrag zelf niet aan kracht doen winnen. Maar dit neemt niet weg, dat met deze conventie opnieuw is gebleken hoezeer groote als kleine Staten gevoelen niet meer geisoleerd in het leven der volkeren te staan; hoezeer meer en meer overeenstemming door allen moet worden gezocht op die punten, waarop de belangen wederzijds met elkander in conflict komen. Het edict van 1906 sloot een eerste hoofdstuk in wat voor Europa het opiumvraagstuk mag heeten af, en toonde den krachtigen wil van China zelf om aan het eeuwenlang opiummisbruik een einde te maken; de Haagsche conventie sluit zulk een tweede hoofdstuk af, hetwelk in meer internationalen zin samenwerking en hulp tegenover deze Chineesche poging toont.

Theoretisch kan men nog beweren, dat de nieuwe conferentie te niet $\mathrm{k}$ an doen geheel het werk der oude conferenties; theoretisch is het mogelijk, maar practisch is het zeer onwaarschijnlijk. Ongetwijfeld zijn nieuwe besprekingen noodig en zullen deze ten aanzien van die landen, die zich buiten de Opiumovereenkomst hebben willen houden, aanvullende bepalingen noodig maken. Doch dit sluit niet in en doet ouk niet verwachten dat het eenmaal tot stand gekomene zal worden vernietigd, en dat 't onmogelijk zou worden geacht voort te gaan op den weg, dien men ter wille van een werkelijk nobel en internationaal doel heeft ingeslagen. De conferentie van $1914 \mathrm{zal}$ hebben te bevestigen en te verbeteren wat die van 1911-1912 onder andere omstandigheden uitwerkte en zal ongetwijfeld, geleerd door ervaringen, welke reeds verkregen zijn, in deze taak gemakkelijker slagen dan dit voor hare voorgangster mogelijk was.

Den Haag.

H. van der Mandere. 